\title{
Behavioral effects induced by antitumor cleronade diterpenes from Casearia sylvestris and in silico interactions with neuron receptors
}

\author{
Éverton José Ferreira de ARAÚJO ${ }^{\mathrm{a}, \mathrm{b}}$, Antônia Amanda Cardoso de ALMEIDA ${ }^{\mathrm{c}}$, Oskar \\ Almeida SILVA ${ }^{\mathrm{c}}$, Iwyson Henrique Fernandes da COSTA ${ }^{\mathrm{b}}$, Luis Mário REZENDE-JÚNIOR ${ }^{\mathrm{b}}$, \\ Francisco das Chagas Alves LIMA ${ }^{\mathrm{c}, \mathrm{d}}$, Alberto José CAVALHEIRO ${ }^{\mathrm{e}}$, Cláudia PESSOA ${ }^{\mathrm{f}}$, Manoel \\ Odorico de MORAES ${ }^{\mathrm{f}}$, Paulo Michel Pinheiro FERREIRA ${ }^{\mathrm{a}, \mathrm{c}, \mathrm{g}, *}$
}

a Postgraduate Program in Pharmaceutical Sciences, Federal University of Piauí, Teresina, Brazil

b Department of Pharmacy, Federal University of Piauí, Teresina, Brazil

c Postgraduate Program in Biotechnology (RENORBIO), Federal University of Piauí, Teresina, Brazil

d Quantum Computational Chemistry Laboratory, Department of Chemistry, State University of Piauí, Teresina, Piauí, Brazil

e Department of Organic Chemisty, Chemistry Institute, State University of São Paulo Júlio de Mesquita Filho, Araraquara, Brazil

${ }^{\mathrm{f}}$ Department of Physiology and Pharmacology, Faculty of Medicine, Federal University of Ceará, Fortaleza, Brazil

${ }^{\mathrm{g}}$ Department of Biophysics and Physiology, Laboratory of Experimental Cancerology, Federal University of Piauí, Teresina, Brazil

\section{A R T I C L E I N F O}

\section{Keywords:}

Casearins

Physiological parameters

Anxiolytic action

Acute toxicity

\begin{abstract}
A B S T R A C T
Ethnopharmacological relevance: Casearia sylvestris is a medicinal plant traditionally used to treat snakebites, wounds, inflammation and gastric ulcers and scientific supports for have demonstrated its antitumor, antihyperlipidemic and antiparasitic properties.

Aim of the study: To assess the effects of a fraction with casearins (FC) on adult mice using classical experimental models of animal behavior and theoretical calculations to verify the interaction of Casearin X (Cas $\mathrm{X})$ with neuron receptors.

Materials and methods: Animals divided in 6 groups ( $\mathrm{n}=9 /$ group) were intraperitoneally treated with vehicle (DMSO 4\%), FC (2.5, 5, 10 and $25 \mathrm{mg} / \mathrm{kg} /$ day) and diazepam (2 mg/kg) for 7 days. Thirty minutes after the last dose of treatment, acute toxicity and behavioral experiments were performed.

Results: The highest dose of FC ( $25 \mathrm{mg} / \mathrm{kg} /$ day) caused diarrhea, weight loss and death of one animal. Elevated plus maze test showed that lower doses $[2.5 \mathrm{mg} / \mathrm{kg} /$ day $(36.4 \pm 5.1 \mathrm{~s})$ and $5 \mathrm{mg} / \mathrm{kg} /$ day $(43.9 \pm 6.2 \mathrm{~s})]$ increased the time spent in open arms (TSOA). Open field test revealed reduction in the number of crossings (54.9\%, $51.1 \%, 48 \%$ and $67.7 \%$ for $2.5,5,10$ and $25 \mathrm{mg} / \mathrm{kg} /$ day, respectively) in all doses of FC studied and decrease of rearings at $25 \mathrm{mg} / \mathrm{kg} /$ day $(\mathrm{p}<0.05)$. Computational calculations showed that the inhibition constant (Ki) for the Cas $\mathrm{X}-\mathrm{D}_{1}$ complex is up to 1000 -fold more favourable than the Cas $\mathrm{X}-\mathrm{GABA}_{\mathrm{A}}$ complex. All $\Delta \mathrm{G}^{\circ}$ values obtained for Cas $\mathrm{X}-\mathrm{D}_{1}$ complexes were more negative than those seen with Cas $\mathrm{X}-\mathrm{GABA}_{\mathrm{A}}$ complexes.

Conclusions: Findings indicate a probable anxiolytic action of the FC since it reduces the number of crossings and rearings and prolonged the time spent in open arms, without sedative and myorelaxant effects, probably due to the interaction of Cas $\mathrm{X}$ with dopaminergic system.
\end{abstract}

\section{Introduction}

Medicinal plants and their derivatives may modify animals' behavior, since some of them are used to induce or treat anxiety, depression or seizures. Then, herbal medicines, whose pharmacological potential is evaluated in animals and neurochemical models, have become a new therapeutic option in clinical psychiatry. The popular usage of such preparations and pharmaceutical derivatives in the treatment of neurological disorders is driven by the fact that these substances are from a natural origin and some activity on central nervous system is available (Zhang, 2004; Silva et al., 2011; Souto-Maior et al., 2011; Almeida et al., 2012; Moreno et al., 2014).

Casearia sylvestris Swartz (Salicaceae), a plant known as "guaçatonga", is popularly used in the treatment of snake poisons, injury, inflammation and gastric ulcers. Phytochemical analyzes demonstrate that a significant portion of ethanol extract of "guaçatonga"

\footnotetext{
* Corresponding author at: Laboratory of Experimental Cancerology, Department of Biophysics and Physiology, Federal University of Piauí, Teresina, Brazil.

E-mail address: pmpf@ufpi.edu.br (P.M.P. FERREIRA).
} 
leaves consists of casearins, clerodane diterpenes responsible for the most of pharmacological properties of this species. Indeed, there is a direct relationship between concentration of casearins and the pharmacological potentiality (Carvalho et al., 1998; Wang et al., 2009; Ferreira et al., 2011; Araújo et al., 2014).

Different parts of C. sylvestris also exhibit activity against Leishmania donovani promastigotes (Mesquita et al., 2005), Trypanosoma cruzi amastigotes (Espíndola et al., 2004; Mesquita et al., 2005), Plasmodium falciparum strains resistant to chloroquine (Mesquita et al., 2007) and Aedes aegypti larvae (Rodrigues et al., 2006). Additionally, leaf methanolic extract shows anti-hyperlipidemic properties, decreasing serum triglycerides and lipases (Schoenfelder et al., 2008), hydroalcoholic extract from dried leaves has antinociceptive capability likely due to the inhibition of an inflammatory mediator and/or by the activation of opioid cascade (Mattos et al., 2007) and the methanolic extract obtained from $C$. sylvestris leaves reduced serum lipids and oxidative stress when orally administered to Swiss mice, prevented arterial thickening induced by high fat diet and diminished in vitro platelet aggregation (Brant et al., 2014).

The cytotoxic activity against different types of cancers is one of the biological activities attributed to the casearins (Itokawa et al., 1990; Carvalho et al., 1998; Wang et al., 2009; Santos et al., 2010; Ferreira et al., 2010, 2011; Araújo et al., 2014; Ferreira et al., 2014). Recently, we showed a great potentiality of a fraction from $C$. sylvestris leaves using in vivo murine and human cancer models after oral and intraperitoneal treatment, revealing tumor growth inhibition rates ranging from $33.3 \%$ to $67.4 \%$ for human lines (colon carcinoma, HCT-116; glioblastoma, SF-295) and from $35.8 \%$ to $90.0 \%$ for Sarcoma 180 cells. Assessments by flow cytometry revealed that this fraction reduces membrane integrity and induces DNA fragmentation and mitochondrial depolarization (Ferreira et al., 2014, 2016).

There are very a few studies describing actions of $C$. sylvestris on the central nervous system (CNS). Since this plant has been used for a long time in the South America, even by natives from Karaja (Brazil) and Shipibo-Conibo (Peru) Indian tribes as an alternative to treat pathologies, it is really important to understand pharmacological and/ or side effects of $C$. sylvestris derived products (Ferreira et al., 2011; Araújo et al., 2014, 2015). Then, this study examines the possible effects of a fraction with casearins (FC) on adult mice using classical experimental models of animal behavior and theoretical calculations to verify the interaction of Casearin $\mathrm{X}$ (Cas $\mathrm{X}$ ) with pharmacological receptors.

\section{Materials and methods}

\subsection{Animals}

Adult male Swiss mice (Mus musculus) with 25-30 g were obtained from the animal facilities of the Federal University of Piauí. They were kept in well-ventilated cages (Alesco, São Paulo) under standard conditions of light ( $12 \mathrm{~h}$ with alternative day and night cycles), temperature $\left(24 \pm 1^{\circ} \mathrm{C}\right)$ and were housed with access to commercial rodent stock diet (Nutrilabor, São Paulo, Brazil) and water ad libitum. All procedures were approved by the Committee on Animal Research at UFPI (\#0102/2011) and they are in accordance with Brazilian (COBEA - Colégio Brasileiro de Experimentação Animal) and international guidelines on the care and use of experimental animals (Directive 2010/63/EU of the European Parliament and of the Council).

\subsection{Obtainment of the fraction with casearins (FC)}

Leaves of $C$. sylvestris were collected at Parque Estadual Carlos Botelho (São Miguel Arcanjo, São Paulo) by researchers of the Chemistry Institute of the São Paulo State University. Voucher specimens (AGS04, AGS05, AGS06, AGS13 and AGS19) were deposited at the Herbarium Maria Eneida P. Kaufmann of the Botanical Institute of
São Paulo, Brazil. The ethanolic extract from the leaves and its fraction were obtained as described in Santos et al. (2010). Dried and powdered leaves of $C$. sylvestris were extracted with ethanol in a stainless steel extractor with solvent reflux during $24 \mathrm{~h}$ at $40{ }^{\circ} \mathrm{C}$. The crude extract was concentrated under reduced pressure (rotary evaporator) and dried in desiccators over silica gel under reduced pressure to yield a dry residue. The extract was fractionated through a solid phase extraction using activated charcoal/silica gel $60-200 \mu \mathrm{m}(1: 1, \mathrm{~m} / \mathrm{m})$ as stationary phase and hexane/ethyl acetate $(95: 5, \mathrm{v} / \mathrm{v})$, ethyl acetate and methanol as the mobile phase, providing three fractions, respectively. The second fraction obtained corresponds to the FC.

Clerodane diterpenes were identified at Núcleo de Bioensaios, Biossíntese e Ecofisiologia de Produtos Naturais - NuBBE, Institute of Chemistry, UNESP (Araraquara, São Paulo, Brazil) using high performance liquid chromatography (HPLC-DAD) as described in Claudino et al. (2013) and nuclear magnetic resonance considering literature netaviedata (Itokawa et al., 1990; Santos et al., 2010). These investigations displayed that FC presents $56.5 \%(\mathrm{mg} / \mathrm{g})$ of the fraction, in which Caseargrewiin F (Cas F) and Cas X are the most present molecules (9.9\% and 14.2\%, respectively) (Ferreira et al., 2014).

\subsection{In vivo protocols}

The fraction with casearins (FC) was solubilized in dimethylsulfoxide (DMSO) 4\% and dissolved in purified water immediately before intraperitoneal (i.p.) injection at doses of 2.5, 5, 10 e $25 \mathrm{mg} / \mathrm{kg}$ during uninterrupted 7 days. Thirty minutes after the last dose of treatment, experiments were performed. Control group received DMSO $4 \%$ in purified water only. It was used diazepam (DZP, Union Chemical, Brazil) at $2 \mathrm{mg} / \mathrm{kg}$ i.p. as positive control diluted with DMSO $4 \%$ in purified water.

\subsection{Plus maze model to study anxiety}

This test is used to evaluate the presence of characteristics of anxiety in rodents (Lister, 1987). The elevated plus maze is made from wood and consists of two open arms $(30 \times 5 \mathrm{~cm})$ and two closed arms $(30 \times 5 \times 25 \mathrm{~cm})$ perpendicularly crossed. The animal is placed $60 \mathrm{~cm}$ above the ground exactly in the intersection of the arms (central platform $5 \times 5 \mathrm{~cm}$ ) with the head in direction to the entrance of the closed arms. For this test, mice were divided into 6 groups $(n=9$ animals/group) and treated as described above.

The animals were placed in the intersection $30 \mathrm{~min}$ after the last dose and observed for $5 \mathrm{~min}$. The parameters quantified were the number of entries in the open arms (NEOA), time spent in the open arms (TSOA) and the total number of entries into open and closed arms. After each animal, the cleaning of the field was performed with a paper towel humidified with alcohol $96^{\circ}$ GL to remove excreta left by prior animals.

\subsection{Open field test to study locomotor activity}

The exploratory activity was verified using an open field made of acrylic (transparent walls and black floor, with dimensions of $30 \times 30 \times 15 \mathrm{~cm}$ ) divided into 9 quadrants and based on the model described by Archer (1973) and Moreno et al. (2014). Animals were divided into 6 groups ( $\mathrm{n}=9$ animals/group) and treated with vehicle (DMSO 4\%), FC (2.5, 5, 10 e $25 \mathrm{mg} / \mathrm{kg})$ and diazepam ( $2 \mathrm{mg} / \mathrm{kg})$ for 7 days. Thirty minutes after the treatment, animals were placed in the center of the open field. Afterwards, the number of intersections or crossings with four legs (spontaneous locomotor activity - SLA), number of self-cleaning behavior (grooming) and number of lifting without lean against the walls (rearing) were accounted for $5 \mathrm{~min}$. After each animal, the cleaning of the field was performed with a paper towel humidified with alcohol $96^{\circ}$ GL to remove excreta left by prior animals. 


\subsection{Rota rod test to study motor coordination}

The test route rod assesses the degree of muscle relaxation or motor incoordination induced by bioactive substances (Carlini and Burgos, 1979). For this test, mice were divided into 6 groups ( $n=9$ animals/ group) and treated as described above. After the administration of the last dose, each mouse was placed with all four feet onto a bar of $2.5 \mathrm{~cm}$ diameter, $25 \mathrm{~cm}$ high from the floor, in a rotation of $17 \mathrm{rpm}$ for a period of $3 \mathrm{~min}$. The duration of permanence in the swivel bar, in seconds (s), and the number of falls, with three renewals at maximum, was recorded.

\subsection{Computational design}

Theoretical calculations were made in the program Gaussian 09 (Frisch et al., 2009). Optimization of the geometry of Cas X, the main component of the FC, was developed using the functional hybrid B3LYP in combination with the base assembly $6-311+\mathrm{G}(\mathrm{d}, \mathrm{p})$. The three-dimensional structure of the likely pharmacological receptors involved in the action of Cas $\mathrm{X}\left(\mathrm{GABA}_{\mathrm{A}}\right.$ and theoretical receptor structure $\mathrm{D}_{1}$ - code PDB 1OZ5) was obtained from the PDB database (Protein Data Bank). After optimization with Cas X, it was verified its interaction in the active site. The docking calculations were developed in the program AUTO DOCK 4.2 (Morris et al., 1998) to verify constant values of inhibition and binding energy between Cas $\mathrm{X}$ and receptors.

\subsection{Statistical analysis}

All results were presented as mean \pm standard error of the mean (SEM). Data were evaluated by analysis of variance (ANOVA) followed by Student-Neuman-Keuls (GraphPad Prism, version 5.0). Differences were considered significant when $\mathrm{p}<0.05$.

\section{Results}

\subsection{Physiological alterations}

During the study, animals that received growing doses of the FC were observed for general toxic aspects, providing an overall estimate of toxicological nature of the substance. Only the highest dose of FC ( $25 \mathrm{mg} / \mathrm{kg} /$ day) caused diarrhea, weight loss and death of one animal.

Elevated plus maze is an experimental model used to investigate the modulation of the state of anxiety and exploratory activity of animals. Outcomes showed that none of the doses decreased the NEOA $(4.2 \pm$ $0.4,4.4 \pm 0.4,2.8 \pm 0.5$ and $1.8 \pm 0.4$ for $2.5,5,10$ and $25 \mathrm{mg} / \mathrm{kg} / \mathrm{day}$, respectively, $\mathrm{p}>0.05)$ when compared to the negative group $(2.6 \pm$ $0.3)$, but statistically significant result was found with diazepam $(7.1 \pm$ $0.8)(p<0.05$, Fig. 1A). If observed the time spent in the open arms (TSOA), there is no influence of higher doses of the fraction $[10 \mathrm{mg} / \mathrm{kg} /$ day $(16.6 \pm 4.3 \mathrm{~s})$ and $25 \mathrm{mg} / \mathrm{kg} /$ day $(11.3 \pm 2.5 \mathrm{~s})]$ on the behavior of mice in comparison with vehicle group $(20.6 \pm 3.7 \mathrm{~s})$ (Fig. 1B). On the other hand, lower doses [2.5 mg/kg/day $(36.4 \pm 5.1 \mathrm{~s})$ and $5 \mathrm{mg} / \mathrm{kg} /$ day $(43.9 \pm 6.2 \mathrm{~s})]$ increased the TSOA when compared to the negative control animals $(20.6 \pm 3.7 \mathrm{~s})(\mathrm{p}<0.05)$. On the other hand, only FC 25 $\mathrm{mg} / \mathrm{kg}$ /day and diazepam $(7.1 \pm 0.6$ and $24.6 \pm 1.6$ entries, respectively) altered the number of entries in comparison with negative control $(13.3 \pm 1.1$ entries, $\mathrm{p}<0.05$, Fig. $1 \mathrm{C})$.

Analysis in the open field test (Fig. 2A) revealed reduction in the number of crossings $(54.9 \%, 51.1 \%, 48 \%$ and $67.7 \%$ ) in all doses of FC studied $(36.7 \pm 2.4,39.8 \pm 3.1,42.9 \pm 4.4$ and $26.3 \pm 2.0$ crossings for $2.5,5,10$ and $25 \mathrm{mg} / \mathrm{kg} /$ day, respectively) when compared to the negative group $(81.4 \pm 6.2$ crossings $)(p<0.05)$. Similarly, crossings' decreasing was also statistically significant between diazepam $(55.7 \pm$ 3.8 crossings) and FC groups $(\mathrm{p}<0.05)$.

Changes were not observed in the number of groomings (Fig. 2B). Meanwhile, the number of rearings (Fig. 2C) decreased at dose of
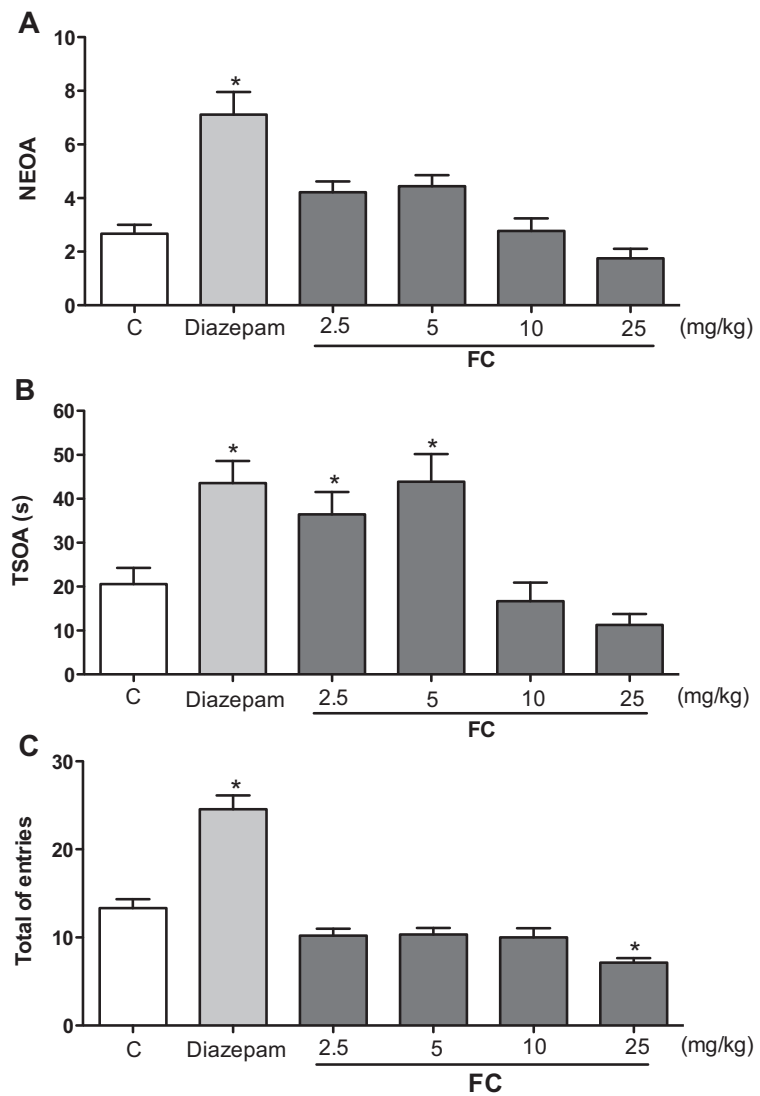

Fig. 1. Physiological analysis of the number of entries in the open arms (NEOA) (A), time spent in the open arms (TSOA) (B) and total number of entries into open and closed arms (C) by the elevated plus maze test in Swiss mice treated with a fraction with casearins (FC) extracted from Casearia sylvestris (2.5, 5, 10 and $25 \mathrm{mg} / \mathrm{kg} /$ day) during 7 days. Results were expressed as mean \pm S.E.M. ( $n=9$ animals/group). ${ }^{*} \mathrm{p}<0.05$ compared to the negative control (C) by ANOVA followed by Student-Newman-Keuls. Negative control received DMSO 4\%. Positive control was treated with diazepam ( $2 \mathrm{mg} / \mathrm{kg} /$ day).

$25 \mathrm{mg} / \mathrm{kg} /$ day $(3.5 \pm 0.5$ rearings $)$ in comparison with negative control and diazepam group $(1.1 \pm 0.4$ and $2.2 \pm 0.3$ rearings $)(\mathrm{p}<0.05)$.

Rota rod test allows evaluating sedative effects (Table 1). FC did not alter the residence time in the swivel bar $(177.4 \pm 1.3,177.8 \pm 1.6$, $178.0 \pm 1.0$ and $174.6 \pm 1.9 \mathrm{~s})$ and maintained the number of falls $(0.3$ $\pm 0.2,0.3 \pm 0.2,0.3 \pm 0.1$ and $0.8 \pm 0.3$ falls at $2.5,5,10$ and $25 \mathrm{mg} /$ $\mathrm{kg} /$ day, respectively) when compared to negative control $(179.0 \pm 0.7 \mathrm{~s}$ and $0.2 \pm 0.1$ falls $)(\mathrm{p}>0.05)$. Meanwhile, diazepam-treated animals presented increase of falls $(1.4 \pm 0.4)$ and reduction in the swivel bar $(161.3 \pm 7.7 \mathrm{~s})$ when comparison with negative control $(\mathrm{p}<0.05)$.

\subsection{Computational outcomes}

Taking into consideration that Cas $\mathrm{X}$ is the main constituent in the fraction, a theoretical investigation based on established models of computational chemistry was carried out to determine the possible mechanism of interaction of Cas $\mathrm{X}$ with receptors in the central nervous system in attempt to analyze the physiological changes found in biological models.

Firstly, it was found that Cas $\mathrm{X}$ has two defined regions with different polarities (nonpolar, A; polar, B) (Fig. 3).

Based on the ligand and receptor structures, it has been possible to point out the more stable thermodynamically interactions in both active sites (Fig. 4). An important topic is how the interaction of the ligand is occurring within the active site. $\mathrm{D}_{1}$ receptor interacts with Cas $\mathrm{X}$ through the nonpolar region A (residues PHE266 and ARG266), which constitutes nonpolar interactions. However, for the complex Cas $\mathrm{X}-\mathrm{GABA}_{\mathrm{A}}$, the complex of lowest inhibition constant does not present 
A
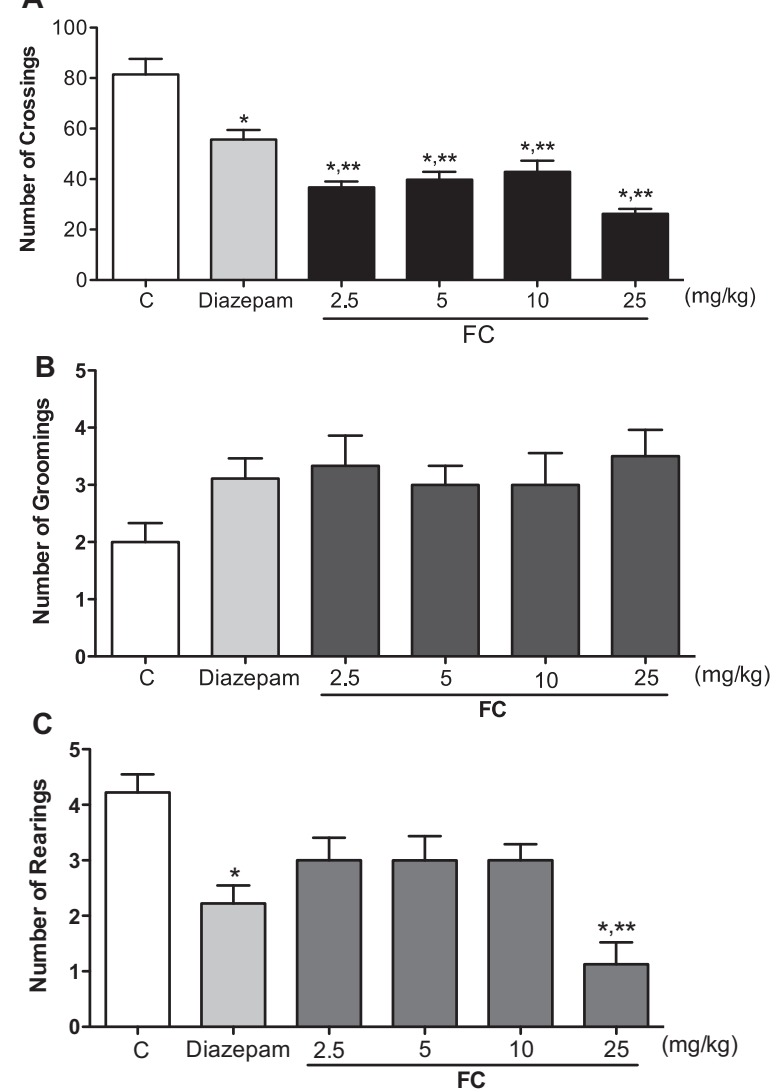

Fig. 2. Physiological analysis of crossings (A), groomings (B) and rearings (C) by the open flied test in Swiss mice treated with a fraction with casearins (FC) extracted from Casearia sylvestris (2.5, 5, 10 and $25 \mathrm{mg} / \mathrm{kg} /$ day) during 7 days. Results were expressed as mean \pm S.E.M. ( $\mathrm{n}=9$ animals/group). ${ }^{*} \mathrm{p}<0.05$ compared to the negative control (C). ${ }^{* *} \mathrm{p}<0.05$ compared to the diazepam group by ANOVA followed by Student-NewmanKeuls. Negative control received DMSO 4\%. Positive control was treated with diazepam ( $2 \mathrm{mg} / \mathrm{kg}$ /day).

\section{Table 1}

Motor coordination analyzed by the rota rod test after treatment with a fraction with casearins (FC) extracted from Casearia sylvestris in Swiss mice after 7 days of treatment at doses of $2.5,5,10$ and $25 \mathrm{mg} / \mathrm{kg} /$ day.

\begin{tabular}{lll}
\hline Group & Number of falls & $\begin{array}{l}\text { Time of permanence in revolving } \\
\text { bar (s) }\end{array}$ \\
\hline Negative control & $0.2 \pm 0.1$ & $179.0 \pm 0.7$ \\
Diazepam & $1.4 \pm 0.4^{*}$ & $161.3 \pm 7.7^{*}$ \\
$\mathbf{2 . 5}$ & $0.3 \pm 0.2$ & $177.4 \pm 1.3$ \\
$\mathbf{5}$ & $0.3 \pm 0.2$ & $177.8 \pm 1.6$ \\
$\mathbf{1 0}$ & $0.3 \pm 0.1$ & $178.0 \pm 1.0$ \\
$\mathbf{2 5}$ & $0.8 \pm 0.3$ & $174.6 \pm 1.9$ \\
\hline
\end{tabular}

Results were expressed as mean \pm S.E.M. ( $n=9$ animals/group) of the number of falls and time spent on the rotary bar.

* $\mathrm{p}<0.05$ compared to the negative control by ANOVA followed by Student-NewmanKeuls. Negative control received DMSO 4\%. Positive control was treated with diazepam $(2 \mathrm{mg} / \mathrm{kg} /$ day $)$.

nonpolar interaction (Fig. 4).

Analysis of interactions with amino acid residues suggested that it was possible to obtain data from inhibition constant $\left(\mathrm{K}_{\mathrm{i}}\right)$ and binding free energy (Gibbs free energy, $\Delta \mathrm{G}^{\circ}$ ), indicating complex featuring which are more spontaneous, stable and likely to occur among Cas X and D1 and GABAA receptors. The largest number of hydrogen bonds within the active site helps for the system stabilization due to a higher thermodynamic favoring. For the Cas $\mathrm{X}-\mathrm{D}_{1}$ complex, the most favorable $\Delta \mathrm{G}^{\circ}$ was $-10.0 \mathrm{kcal} / \mathrm{mol}$, while for the Cas $\mathrm{X}-\mathrm{GABA}_{\mathrm{A}}$ complex, $\Delta \mathrm{G}^{\circ}$ was $-7.5 \mathrm{kcal} / \mathrm{mol}$ (Table 2 ).

\section{Discussion}

Most of these discoveries of novel bioactive substances use laboratory animals to generate information that makes possible to predict adverse effects of drugs, cosmetics, foodstuffs and plant derivatives to human health. Basically, the observation of body weight, food consumption, hematological and biochemical evaluation of biological fluids, physiological and histopathological analysis, as well as neurological and functional assays complement the general toxicological evaluation based on acute, sub chronic and chronic toxicity. The screening with behavioral models aims to quantify and distinguish the presence of subtle biological changes that may possibly be related to lesions in the CNS from various sources. From this arises the interest in performing the neuropharmacological evaluation of pharmacologically active constituents (Steinberg, 1987; Ferreira et al., 2009; Magalhães et al., 2010; Basu and Head, 2010; Araújo et al., 2014).

Casearia sylvestris is commonly found in the Americas, from Cuba, Antilleans and Porto Rico to Mexico, Brazil, Bolivia, Peru and Argentina. In Brazil, it is distributed from north to south, basically in Cerrado and Atlantic Forest (Little and Wadsworth, 1964; Hack et al., 2005). Several studies have demonstrated biological activities of extracts, fractions and compounds from C. sylvestris, which validates, at least in part, empirical knowledge obtained in ethnopharmacological investigations (Borges et al., 2000; Oberlies et al., 2002; Carvalho et al., 2009; Ferreira et al., 2011; Bou et al., 2013, 2014; Brant et al., 2014; Ferreira et al., 2014, 2016). However, there are a few reports about the effects of this plant on the central nervous system.

Then, this study evaluated the cognitive and behavioral profile of mice treated with a fraction with casearins. It was carried out using a fraction composed by a mixture of casearins since its represents the most folk approach in etnopharmacological uses by Brazilian population. Moreover, it is likely that distinct bioactive terpenoids may jointly or independently contribute to the biological effects (Ferreira et al., 2011; Araújo et al., 2015).

Initially, the animals were evaluated to stipulate a general estimate of toxicological nature of the fraction with casearins. The obvious signal of toxicity found was diarrhea and death of one animal, though all animals in the highest dose also presented apparent decrease in mobility and locomotion. Recently, we also showed that FC at $25 \mathrm{mg} / \mathrm{kg} /$ day causes diarrhea and loss of weight (Ferreira et al., 2016). These findings were followed by behavioral tests to provide evidence if the FC alter the emotional state of animals.

All behaviour examinations include diazepam as positive control. This drug was chosen as standard because several reports have demonstrated the capacity of diazepam to modulate psychiatry conditions in mammals (Walf and Frye, 2007; Almeida et al., 2012; Marques et al., 2012; Pires et al., 2013; Moreno et al., 2014). Indeed, benzodiazepines present a range of actions - sedative/hypnotic, anxiolytic, anticonvulsant and muscle relaxant - combined with low toxicity and alleged lack of dependence potential. However, patients might become dependent on benzodiazepines after chronic use (Tyrer et al., 1983; Ashton, 2005). In this context, gamma-amino butyric acid (GABA) is the most important inhibitory neurotransmitter in the mammalian brain, representing nearly $30 \%$ of all synapses in the whole brain. GABAergic neurones mediate pre-synaptic inhibition by depressing the release of neurotransmitter at excitatory input synapse, and post-synaptic inhibition by depressing synaptic excitation of the principal neuron. When benzodiazepines react at their receptor site, which is actually situated on the GABA receptor, the combination acts as a booster to the actions of GABA making the neuron more resistant to excitation. Several studies showed that benzodiazepines were able to facilitate both types of inhibition, indicating that the effects of the benzodiazepines were in fact due to an interaction with the GABAergic transmission process. That is, BZDs do not activate $\mathrm{GABA}_{\mathrm{A}}$ receptors directly but, instead, are positive allosteric modulators of the effects of GABA and allow lower concentrations of this neurotransmitter to open 


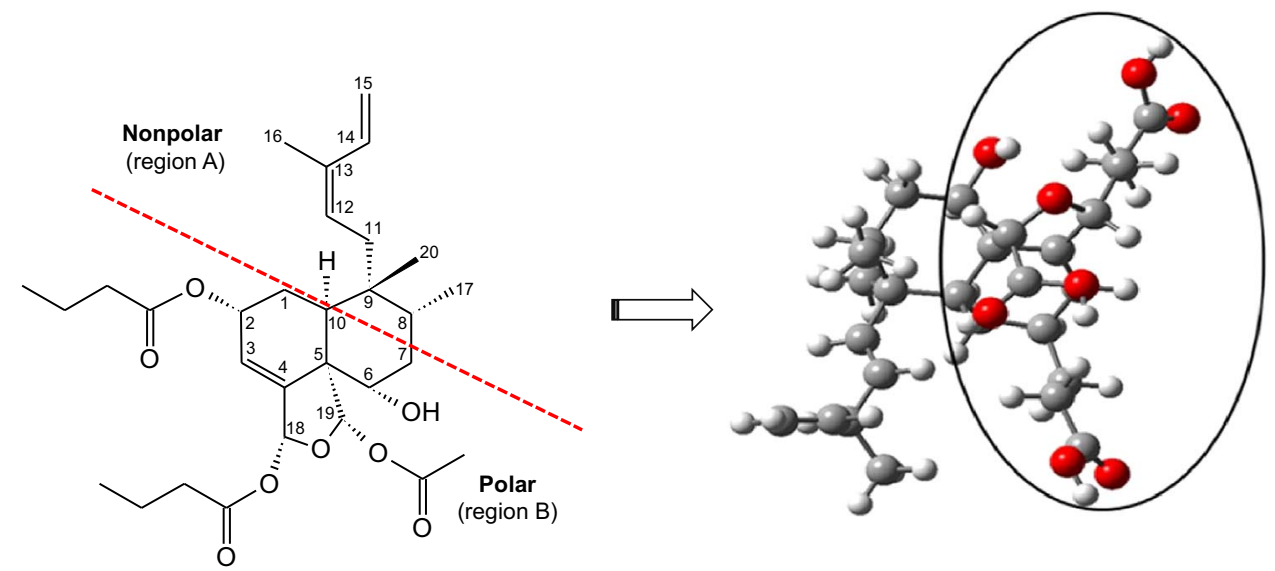

Fig. 3. Casearin $\mathrm{X}$ with defined regions and different polarities. Optimized structure was calculated in level of B3LYP theory.

the $\mathrm{Cl}^{-}$channels. As a consequence of the enhancement of GABA's inhibitory activity caused by benzodiazepines, the brain's output of excitatory neurotransmitters including norepinephrine, serotonin, dopamine and acetylcholine is reduced (Raab and Gummit, 1977; Sigel and Steinmann, 2012; Miller and Aricescu, 2014).

FC reduced, in a dose-dependent way, the NEOA in all doses $(2.5,5$, 10 and $25 \mathrm{mg} / \mathrm{kg} /$ day) and the TSOA in higher doses (10 and $25 \mathrm{mg} /$ $\mathrm{kg}$ /day) when compared to the diazepam group. These findings were carried out using the plus maze test, which consists of a more specific anxiety model for the assessment of anxiolytic drugs with capacity to reduce the rejection that animals present to go to the open arms, since this behavior is conditioned by the fear or stress in aversive environments (Rodgers et al., 1995; Jardim et al., 1999; Carola et al., 2002). Beyond its utility as a model to detect anxiolytic effects of benzodiazepine-related compounds, the elevated plus maze can be used as a behavioral assay to study the brain sites and mechanisms (e.g., GABA, glutamate, serotonin, hypothalamic-pituitary-adrenal axis neuromodulators) underlying anxiety behavior (Walf and Frye, 2007). Knowing that this test is based on the natural aversion of rodents to open spaces, these discoveries suggest that FC has anxiolytic effects in lower doses and similar results to those seen with diazepam, maybe indicating distinct physiological responses in a dose-dependent way. Since typical anxiolytic medications, such as diazepam, increase the frequency and
Table 2

Inhibition constant $\left(\mathrm{K}_{\mathrm{i}}\right)$ and Gibbs free energy $\left(\Delta \mathrm{G}^{\circ}\right)$ for the most stable complexes among Casearin $\mathrm{X}$ and $\mathrm{D}_{1}$ and $\mathrm{GABA}_{\mathrm{A}}$ receptors.

\begin{tabular}{|c|c|c|c|c|c|}
\hline \multirow[t]{2}{*}{ Complex } & \multicolumn{2}{|l|}{$\mathbf{K}_{\mathbf{i}}$} & \multicolumn{3}{|c|}{$\Delta \mathbf{G}^{\circ}$} \\
\hline & $\begin{array}{l}\text { Casearin } \\
\text { X-D1 }\end{array}$ & $\begin{array}{l}\text { Casearin } \\
\text { X-GABA A }_{\mathbf{A}}\end{array}$ & Selectivity & $\begin{array}{l}\text { Casearin } \\
\text { X-D1 }\end{array}$ & $\begin{array}{l}\text { Casearin } \\
\mathbf{X}-\mathbf{G A B A} \mathbf{A}_{\mathbf{A}}\end{array}$ \\
\hline & $(\mathrm{nM})$ & $(\mu \mathrm{M})$ & Index ${ }^{\mathrm{a}}$ & (kcal/mol) & (kcal/mol) \\
\hline 1 & 104.52 & 5.61 & 53.67 & -10.00 & -7.50 \\
\hline 2 & 261.25 & 28.91 & 110.66 & -8.23 & -6.08 \\
\hline 3 & 396.53 & 397.54 & 1002.54 & -6.89 & -4.64 \\
\hline
\end{tabular}

${ }^{a} K_{i}$ for Casearin X-GABA $A$ / $K_{i}$ for Casearin X-D1.

duration of the entries in the open arms (Almeida et al., 2012), while diazepam proportionally expanded NEOA and TSOA, FC did not altered the NEOA but prolonged the time of animals spent in open arms, proposing that biological actions of the $\mathrm{FC}$ are not equally correspondingly to those commonly seen with diazepam.

Open field test is used to describe the motor activity of mice subjected to open spaces and also to corroborate the anxiety level when evaluate the amount of rearings (exploratory behavior) and groomings (immobility when performing self-cleaning). Grooming is an important behavior when anxiety studies are decided and it increases or

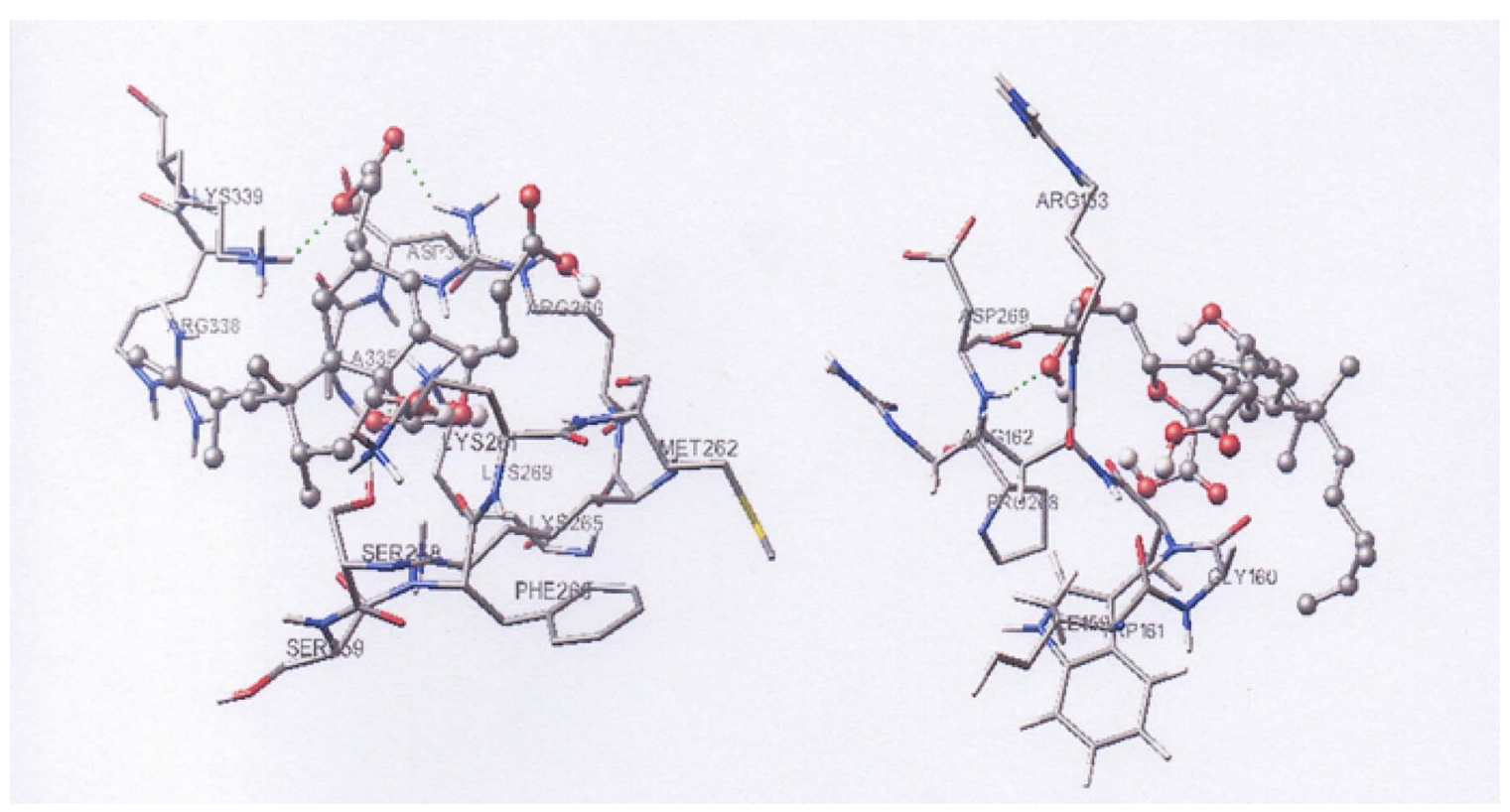

Fig. 4. Structures thermodynamically more stable after analysis of molecular docking between Casearin X and D1 and GABAA receptors, respectively. 
diminishes when the anxiety level augments or is absent, respectively (Archer, 1973; Mataqueiro et al., 2004; Bailey and Crawley, 2009; Neumann et al., 2011). FC caused reduction of crossings and rearings but not altered groomings and its effects were better than those found with diazepam, especially at higher doses. Such findings emphasize the anxiolytic action of FC when associated with augmented TSOA.

Next, the rota rod test, a method frequently used to measure changes in motor coordination and muscle tone of rodents (Silva et al., 2007; Gomes et al., 2010), revealed that none of the doses changed the number of falls and time of permanence in revolving bars, which indicates that the fraction did not interfere upon the spontaneous locomotor activity, has no sedative and/or myorelaxing effects such as seen with the anxiolytic compound diazepam and did not cause movement injuries to the animals.

Previously, Silva et al. (2006) reported that animals subjected to oral gavage treatment with the aqueous extract of guaçatonga $(20 \mathrm{mg} /$ $\mathrm{kg}$ ) for 75 days presented inhibiting of the CNS enzymes NTPDase, 5nucleotidase and $\mathrm{Na}+/ \mathrm{K}+-\mathrm{ATPase}$ and reduced the acetylcholine degradation rate. Moreover, Rodrigues et al. (2008) reported that "Quilombolas" people have used the decoction of C. sylvestris leaves to treat insomnia, especially in children and elders. This information is confronted by our results, since no evidence of sedative or hypnotic action of the FC was found in the rota rod test. All these data indicate that $C$. sylvestris possesses a general neurochemical effect, since important enzymes from the purinergic, cholinergic and other processes were affected, indicating that $C$. sylvestris can exert some modulatory action on the CNS and, eventually, causes behavioral changes as described in this study.

Based on the divergent outcomes between FC and diazepam, and knowing diazepam as a benzodiazepine with anxiolytic activity and capacity to increase the action of $\gamma$-aminobutyric acid (GABA) on $\mathrm{GABA}_{\mathrm{A}}$ receptors, we proposed an additional mechanism involved in the reduction of the SLA in a GABAergic system independent way (Lilly and Tietz, 2000). It is likely that this property of the FC be linked to the action on the dopaminergic system. Schindler and Carmona (2002) reported that cocaine and other dopamine reuptake inhibitors increased the SLA in rodents. On the other hand, D1 antagonists decrease this activity in a similar manner seen in FC-treated animals.

Examinations in the Cas X structure revealed that this molecule has two distinct regions with different forms of intermolecular interactions. The region A has a totally non-polar character compound by aliphatic carbons, which may carry out Van der Waals interactions. Meanwhile, region $\mathrm{B}$ has a character polar predominantly with three carboxylic acid groups ( $\mathrm{COOH})$, an ether group (-O-) and an alcohol group (OH) that can make hydrogen bonds within the active site of $\mathrm{GABA}_{\mathrm{A}}$ and $\mathrm{D}_{1}$ receptors. Moreover, region $\mathrm{B}$ has a large electron density, which suggests a region of higher interaction between Cas $\mathrm{X}$ and the receptor active site. This probably is involved in the interaction and improves stability of the complex. These results showed that the inhibition constant for the Cas $\mathrm{X}-\mathrm{D}_{1}$ complex is up to 1000 -fold more favourable than the Cas $\mathrm{X}-\mathrm{GABA}_{\mathrm{A}}$ complex. Confirming such outcomes, all $\Delta \mathrm{G}^{\circ}$ values obtained for Cas $\mathrm{X}-\mathrm{D}_{1}$ complexes were more negative than those seen with Cas $\mathrm{X}-\mathrm{GABA}_{\mathrm{A}}$ complexes. Investigations have shown that more negative values propose system spontaneity, and, consequently, improved stability of the complex (Wiggers et al., 2011). These findings are in agreement with experimental data obtained by Cueva et al. (2011) who observed a more stable inhibition constant for the complex at $20 \mathrm{nM}$, as well as hydrogen bonds occurring between the ligant and $\mathrm{D}_{1}$ receptor through the residues of SER198, ASP103, ASN292 and aromatic interaction between PHE288 and PHE203 with the ligant. Then, molecular docking also showed amino acid residues that promote direct interaction between Cas X and tested receptors. At $\mathrm{D}_{1}$ receptor, Cas X makes two hydrogen bonds with LYS339 and ASP39, while in $\mathrm{GABA}_{\mathrm{A}}$ receptor only the amino acid ARG162 makes hydrogen bond with Cas $\mathrm{X}$.

Recently, detailed studies about the role of FC on the oxidative stress revealed that it has good in vitro antioxidant potential on free radicals. On the other hand, biochemical and enzimatic profile of hippocampus and striatum from FC-treated mice in similar doses suggest that FC presents scavenger action for lipid peroxidation, since it reduced generation of TBARS (thiobarbituric acid reactive substances) only (Araújo et al., 2015). Despite these diferences from in vitro and in vivo evaluations, which probably involve the liver basic machinery and its biochemical processes such as oxidation and hidroxilation in absence of hepatic injury (Araújo et al., 2015), FC showed a new side of its pontentiality, specially taking into consideration that oxidative stress directly participate in the genesis and progression of many diseases such as cancer, diabetes, cardiovascular and neurological illnesses (e.g., Alzheimer and Parkinson diseases) and aging process. Life expectancy increasing becomes crucial to develop new strategies and therapies to combat chronic diseases (Ferreira et al., 2011; Krishnaiah et al., 2011; Alam et al., 2013).

Since the exploratory behavior and locomotor pattern of mice are factors directly connected to their condition of anxiety, which in turn may be a consequence of neurochemical changes or damage to the central nervous system (Steinberg, 1987; Lister, 1990; Bellinger, 2001; Viaud-Delmon, et al., 2011; Silva et al., 2014), there is a probable association between behavioral changes and neuronal action. Herein, though FC did not modify reflexes, the animals manifested signs of toxicity such as diarrhea and weight loss, and they may cause reduction in spontaneous and exploratory locomotor activity. Interestingly, we have already demonstrated that FC-treated animals exhibited alterations suggestive of neurotoxicity (Araújo et al., 2015), indicating precaution to consume medicinal formulations based on C. sylvestris.

\section{Conclusions}

All findings indicate a probable anxiolytic action of casearins found in $\mathrm{FC}$ since it reduces the number of crossings and rearings and prolonged the time spent in open arms, without sedative and myorelaxant effects. Apparently, GABAergic system is not involved in the behaviour changes and molecular docking studies noticed Cas $\mathrm{X}$ interaction with other neuronal pathways, such as the dopaminergic system and its $\mathrm{D}_{1}$ receptor. Some in vivo mechanistic investigations are in progress to supplement this data.

\section{Acknowledgments}

We wish to thank the Federal Brazilian Agency "Conselho Nacional de Desenvolvimento Científico e Tecnológico” [CNPq (\#484286/20110)] and Fundação de Amparo à Pesquisa do Estado do Piauí [FAPEPI (\#034/2012-PPP)] for financial support in the form of grants. We also grateful to Rivelilson Mendes de Freitas (in memorian), a great researcher that extensively contributed for this work.

\section{References}

Alam, M.N., Bristi, N.J., Rafiquzzaman, M., 2013. Review on in vivo and in vitro methods evaluation of antioxidant activity. Saudi Pharm. J. 21, 143-152.

Almeida, A.A.C., Costa, J.P., Carvalho, R.B.F., Sousa, D.P., Freitas, R.M., 2012 Evaluation of acute toxicity of a natural compound (+)-limonene epoxide and its anxiolytic-like action. Brain Res. 1448, 56-62.

Ashton, H., 2005. The diagnosis and management of benzodiazepine dependence. Curr. Opin. Psychiatry 18, 249-255.

Araújo, E.J.F., Lopes, D.Y.M., Freitas, R.M., Ferreira, P.M.P., 2014. Toxicology of the medicinal plant Casearia sylvestris Swartz: a literature review. Rev. Cienc. Farm. Basic. Appl. 35, 355-361.

Araújo, E.J.F., Oliveira, G.A.L.D., Sousa, L.Q., Bolzani, V.D., Cavalheiro, A.J., Tome, A.R., Peron, A.P., Santos, A.G., Citó, A.M.G.L., Pessoa, C., Freitas, R.M., Ferreira, P.M.P., 2015. Counteracting effects on free radicals and histological alterations induced by a fraction with casearins. An. Acad. Bras. Cienc. 87, 1791-1807.

Archer, J., 1973. Tests for emotionality in rats and mice: a review. Animal Behav. 21, $205-235$.

Bailey, K.R., Crawley, J.N., 2009. Anxiety-related behaviors in mice. In: Buccafusco, J.J. (Ed.), Methods of Behavior Analysis in Neuroscience. CRC Press/Taylor \& Francis, Boca Raton (FL), Chapter 5. 
Basu, N., Head, J., 2010. Mammalian wildlife as complementary models in environmental neurotoxicology. Neurotoxicol. Teratol. 32, 114-119.

Bellinger, D.C., 2001. Future directions for neurobehavioral studies of environmental neurotoxicants. Neurotoxicology 22, 645-656.

Borges, M.H., Soares, A.M., Rodrigues, V.M., Andrião-Escarso, S.H., Diniz, H., Hamaguchi, A., Quintero, A., Lizano, S., Gutiérrez, J.M., Giglio, J.R., HomsiBrandeburgo, M.I., 2000. Effects of aqueous extract of Casearia sylvestris (Flacourtiaceae) on actions of snake and bee venoms and on activity of phospholipases A $\mathrm{A}_{2}$. Comp. Biochem. Physiol. B Biochem. Mol. Biol. 127, 21-30.

Bou, D.D., Lago, J.H.G., Figueiredo, C.R., Matsuo, A.L., Guadagnin, R.C., Soares, M.G., Sartorelli, P., 2013. Chemical composition and cytotoxicity evaluation of essential oil from leaves of Casearia sylvestris, its main compound a-Zingiberene and derivatives. Molecules 18, 9477-9487.

Bou, D.D., Tempone, A.G., Pinto, E.G., Lago, J.H.G., Sartorelli, P., 2014. Antiparasitic activity and effect of casearins isolated from Casearia sylvestris on Leishmania and Trypanosoma cruzi plasma membrane. Phytomedicine 21, 676-681.

Brant, N.M.F., Gasparotto, F.M., Araújo, V.O., Maraschin, J.C., Ribeiro, R.C.L., Lourenço, E.L.B., Junior, E.L.C., Junior, A.G., 2014. Cardiovascular protective effects of Casearia sylvestris Swartz in Swiss and C57BL/6 LDLr-null mice undergoing high fat diet. J. Ethnopharmacol. 154, 419-427.

Carlini, E.A., Burgos, V., 1979. Screening farmacológico de ansiolíticos: metodologia laboratorial e comparação entre diazepam e clorobenzepam. Rev. Assoc. Bras. Psiquiatr., 25-31.

Carola, V., D'Olimpio, F., Brunamonti, E., Mangia, F., Renzi, P., 2002. Evaluation of the elevated plus-maze and open-field tests for the assessment of anxiety-related behaviour in inbred mice. Behav. Brain Res. 134, 49-57.

Carvalho, P.R.F., Furlan, M., Young, M.C.M., Kingston, D.G.I., Bolzani, V.S., 1998. Acetylated DNA-damaging clerodane diterpenes from Casearia sylvestris. Phytochemistry 49, 1659-1662.

Carvalho, E.S., Santos, A.G., Cavalheiro, A.J., 2009. Identificação de diterpenos clerodânicos em diferentes órgão de Casearia sylvestris Sw. Rev. Cienc. Farm. Basic. Apl. 30, 277-284.

Claudino, J.C., Sacramento, L.V.S., Koch, I., Santos, H.A., Cavalheiro, A.J., Tininis, A.G., Santos, A.G., 2013. Evaluation of morpho-anatomical and chemical differences between varieties of the medicinal plant Casearia sylvestris Swartz. An. Acad. Bras. Cienc. 85, 1253-1265.

Cueva, J.P., Gallardo-Godoy, A., Juncosa-Júnior, J.I., Vidi, P.A., Lill, M.A., Watts, V.J., Nichols, D.E., 2011. Probing the steric space at the floor of the $\mathrm{d}_{1}$ dopamine receptor orthosteric binding domain: $7 \alpha-, 7 \beta-, 8 \alpha-$, and $8 \beta$-Methyl substituted dihydrexidine analogues. J. Med. Chem. 54, 5508-5521.

Espíndola, L.S., Vasconcelos-Júnior, J.R., Mesquita, M.L., Marquié, P., Paula, J.E., Mambu, L., Santana, J.M., 2004. Trypanocidal activity of a new diterpene from Casearia sylvestris var. lingua. Planta Med. 70, 1093-1095.

Ferreira, P.M.P., Carvalho, A.F.U., Farias, D.F., Cariolano, N.G., Melo, V.M.M., Queiroz, M.G.R., Martins, A.M.C., Machado-Neto, J.G., 2009. Larvicidal activity of the water extract of Moringa oleifera seeds against Aedes aegypti and its toxicity upon laboratory animals. An. Acad. Bras. Cienc. 81, 207-216.

Ferreira, P.M.P., Santos, A.G., Tininis, A.G., Costa, P.M., Cavalheiro, A.J., Bolzani, V.S., Moraes, M.O., Costa-Lotufo, L.V., Montenegro, R.C., Pessoa, C., 2010. Casearin X exhibits cytotoxic effects in leukemia cells triggered by apoptosis. Chem. Biol. Interact. 188, 497-504.

Ferreira, P.M.P., Costa-Lotufo, L.V., Moraes, M.O., Barros, F.W.A., Martins, A.M.A., Cavalheiro, A.J., Bolzani, V.S., Santos, A.G., Pessoa, C., 2011. Folk uses and pharmacological properties of Casearia sylvestris: a medicinal review. An. Acad. Bras. Cienc. 83, 1373-1384.

Ferreira, P.M.P., Militão, G.C.G., Lima, D.J.B., Costa, N.D.J., Machado, K.C., Santos, A.G., Cavalheiro, A.J., Bolzani, V.S., Silva, D.H.S., Pessoa, C., 2014. Morphological and biochemical alterations activated by antitumor clerodane diterpenes. Chem. Biol. Interact. 222, 112-125.

Ferreira, P.M.P., Bezerra, D.P., Silva, J.N., Costa, M.P., Ferreira, J.R.O., Alencar, N.M.N., Figueiredo, I.S.T., Cavalheiro, A.J., Machado, C.M.L., Chammas, R., Alves, A.P.N.N., Moraes, M.O., Pessoa, C., 2016. Preclinical anticancer effectiveness of a fraction from Casearia sylvestris and its component Casearin X: in vivo and ex vivo methods and microscopy examinations. J. Ethnopharmacol. 186, 270-279.

Frisch, M.J., Trucks, G.W., Schlegel, H.B., Scuseria, G.E., Robb, M.A., Cheeseman, J.R., Montgomery, J.A., Jr., Vreven, T., Kudin, K.N., Burant, J.C., Millam, J.M., Iyengar, S.S., Tomasi, J., Barone, V., Mennucci, B., Cossi, M., Scalmani, G., Rega, N., Petersson, G.A., Nakatsuji, H., Hada, M., Ehara, M., Toyota, K., Fukuda, R., Hasegawa, J., Ishida, M., Nakajima, T., Honda, Y., Kitao, O., Nakai, H., Klene, M., Li, X., Knox, J.E., Hratchian, H.P., Cross, J.B., Bakken, V., Adamo, C., Jaramillo, J., Gomperts, R., Stratmann, R.E., Yazyev, O., Austin, A.J., Cammi, R., Pomelli, C., Ochterski, J.W., Ayala, P.Y., Morokuma, K., Voth, G.A., Salvador, P., Dannenberg, J.J., Zakrzewski, V.G., Dapprich, S., Daniels, A.D., Strain, M.C., Farkas, O., Malick, D.K., Rabuck, A.D., Raghavachari, K., Foresman, J.B., Ortiz, J.V., Cui, Q., Baboul, A.G., Clifford, S., Cioslowski, J., Stefanov, B.B., Liu, G., Liashenko, A., Piskorz, P., Komaromi, I., Martin, R.L., Fox, D.J., Keith, T., Al-Laham, M.A., Peng, C.Y., Nanayakkara, A., Challacombe, M., Gill, P.M.W., Johnson, B., Chen, W., Wong, M.W., Gonzalez, C., Pople, J.A., 2009. Gaussian 09, Revision A.02. Gaussian, Inc. Wallingford, CT.

Gomes, P.B., Feitosa, M.L., Silva, M.I.G., Noronha, E.C., Moura, B.A., Venâncio, E.T., Rios, E.R.V., Sousa, D.P., Vasconcelos, S.M.M., Fonteles, M.M.F., Sousa, F.C.F., 2010. Anxiolytic-like effect of the monoterpene 1,4-cineole in mice. Pharmacol. Biochem. Behav. 96, 287-293.

Hack, C., Longhi, S.J., Boligon, A.A., Murari, A.B., Pauleski, D.T., 2005. Análise fitossociológica de um fragmento de floresta estacional decidual no município de Jaguari, RS. Cienc. Rural 35, 1083-1091.
Itokawa, H., Totsuka, N., Morita, H., Takeya, K., Iitaka, Y., Schenkel, E.P., Motidome, M., 1990. New antitumor principles, casearins A-F, for Casearia sylvestris Sw. (Flacourtiaceae). Chem. Pharm. Bull. 38, 3384-3388.

Jardim, M.C., Nogueira, R.L., Graeff, F.G., Nunes-De-Souza, R.L., 1999. Evaluation of the elevated T-maze as an animal model of anxiety in the mouse. Brain Res. Bull. 48, 407-411.

Krishnaiah, D., Sarbatly, R., Nithyanandam, R., 2011. A review of the antioxidant potential of medicinal plant species. Food. Bioprod. Process. 89, 217-233.

Lilly, S.M., Tietz, E.I., 2000. Chronic cocaine differentially affects diazepam's anxiolytic and anticonvulsant actions. Brain Res. 882, 139-148.

Lister, R., 1987. The use of a plus-maze to measure anxiety in the mouse. Psychopharmacology 92, 180-185.

Lister, R.G., 1990. Ethologically-based animal models of anxiety disorders. Pharmacol. Ther. 46, 321-340.

Little, E.L., Wadsworth, F.H., 1964. Common Trees of Puerto Rico and The Virgin Islands. U.S. Dept. of Agriculture, Forest Service, Washington, D.C.

Magalhães, H.I.F., Ferreira, P.M.P., Moura, E.S., Torres, M.R., Alves, A.P.N.N., Pessoa, O.D.L., Costa-Lotufo, L.V., Moraes, M.O., Pessoa, C., 2010. In vitro and in vivo antiproliferative activity of Calotropis procera stem extracts. An. Acad. Bras. Cienc $82,407-416$.

Marques, T.H.C., Melo, C.H.S., Freitas, R.M., 2012. In vitro evaluation of antioxidant, anxiolytic and antidepressant-like effects of the Bellis perennis extract. Rev. Bras. Farmacogn. 22, 1044-1052.

Mataqueiro, M.I., D’Angelis, F.H.F., De-Caroli-Neto, A., Rossi, C.A., Queiroz-Neto, A., 2004. Comparative study of the sedative and antinociceptive effects of levomepromazine, azaperone and midazolam in laboratory animals. Arq. Bras. Med. Vet. Zootec. 56, 340-345.

Mattos, E.S., Frederico, M.J.S., Colle, T.D., Pieri, D.V., Peters, R.R., Piovezan, A.P., 2007. Evaluation of antinociceptive activity of Casearia sylvestris and possible mechanism of action. J. Ethnopharmacol. 112, 1-6.

Mesquita, M.L., Desrivot, J., Bories, B., Fournet, A., Paula, J.E., Grellier, P., Espindola, L.S., 2005. Antileishmanial and trypanocidal activity of Brazilian Cerrado plants. Mem. Inst. Oswaldo Cruz 100, 783-787.

Mesquita, M.L., Grellier, P., Mambu, L., Paula, J.E., Espindola, L.S., 2007. In vitro antiplasmodial activity of Brazilian Cerrado plants used as traditional remedies. J. Ethnopharmacol. 110, 165-170.

Miller, P.S., Aricescu, A.R., 2014. Crystal structure of a human $\mathrm{GABA}_{\mathrm{A}}$ receptor. Nature 512, 270-275.

Moreno, L.C., Oliveira, G.Z.S., Cavalcanti, I.M., Santos-Magalhães, N.S., Rolim, H.M., Freitas, R.M., 2014. Development and evaluation of liposomal formulation containing nimodipine on anxiolytic activity in mice. Pharmacol. Biochem. Behav. $116,64-68$.

Morris, G.M., Goodsell, D.S., Halliday, R.S., Huey, R., Hart, W.E., Belew, R.K., Olson, A.J., 1998. Automated docking using a Lamarckian genetic algorithm and an empirical binding free energy function. J. Comput. Chem. 19, 1639-1662.

Neumann, I.D., Wegener, G., Homberg, J.R., Cohen, H., Slattery, D.A., Zohar, J., Olivier, J.D.A., Mathé, A.A., 2011. Animal models of depression and anxiety: What do they tell us about human condition? Prog. Neuropsychopharmacol. Biol. Psychiatry 35, 1357-1375.

Oberlies, N.H., Burgess, J.P., Navarro, H.A., Pinos, R.E., Fairchild, C.R., Peterson, R.W., Soejarto, D.D., Farnsworth, N.R., Kinghorn, A.D., Wani, M.C., Wall, M.E., 2002. Novel bioactive clerodane diterpenoids from the leaves and twigs of Casearia sylvestris. J. Nat. Prod. 65, 95-99.

Pires, L.F., Costa, L.M., Silva, O.A., Almeida, A.A.C., Cerqueira, G.S., Sousa, D.P., Freitas, R.M., 2013. Anxiolytic-like effects of carvacryl acetate, a derivative of carvacrol in mice. Pharmacol. Biochem. Behav. 112, 42-48.

Raab, W., Gummit, R.J., 1977. Anticonvulsant action of diazepam: Increase of cortical post-synaptic inhibition. Epilepsia 18, 117-120.

Rodgers, R.J., Cole, J.C., Aboualfa, K., Stephenson, L.H., 1995. Ethopharmacological analysis of the effects of putative 'anxiogenic' agents in the mouse elevated plusmaze. Pharmacol. Biochem. Behav. 52, 805-813.

Rodrigues, A.M.S., Paula, J.E., Degallier, N., Molez, J.F., Espíndola, L.S., 2006. Larvicidal activity of some cerrado plant extracts against Aedes Aegypti. J. Am. Mosq. Control Assoc. 22, 314-317.

Rodrigues, E., Tabach, R., Galduróz, J.C.F., Negri, G., 2008. Plants with possible anxiolytic and/or hypnotic effects as indicated by three Brazilian cultures -Indian. Afro-Brazilian, and River-Dweller. Stud. Nat. Prod. Chem. 35, 549-595.

Santos, A.G., Ferreira, P.M.P., Vieira-Júnior, G.M., Perez, C.C., Tininis, A.G., Silva, G.H., Bolzani, V.S., Costa-Lotufo, L.V., Pessoa, C., Cavalheiro, A.J., 2010. Casearin X, Its degradation product and other clerodane diterpenes from leaves of Casearia sylvestris: Evaluation of cytotoxicity against normal and tumor human cells. Chem. Biodivers. 7, 205-215.

Schindler, C.W., Carmona, G.N., 2002. Effects of dopamine agonists and antagonists on locomotor activity in male and female rats. Pharmacol. Biochem. Behav. 72, 857-863.

Schoenfelder, T., Pich, C.T., Geremias, R., Ávila, S., Daminelli, E.N., Pedrosa, R.C., Bettiol, J., 2008. Antihyperlipidemic effect of Casearia sylvestris methanolic extract. Fitoterapia 79, 465-467.

Sigel, E., Steinmann, M., 2012. Structure, function, and modulation of $\mathrm{GABA}_{\mathrm{A}}$ receptors. JBC 287, 40224-40231.

Silva, A.P.S.C.L., Lopes, J.S.L., Vieira, P.S., Pinheiro, E.E.A., Silva, M.L.G., Filho, J.C.C.L.S., Júnior, J.S.C., David, J.M., Freitas, R.M., 2014. Behavioral and neurochemical studies in mice pretreated with garcinielliptone FC in pilocarpineinduced seizures. Pharmacol. Biochem. Behav. 124, 305-310.

Silva, A.C., Balz, D., Souza, J.B.D.A., Morsch, V.M., Corrêa, M.C., Zanetti, G.D., Manfron, M.P., Schetinger, M.R.C., 2006. Inhibition of NTPDase, $5^{\prime}$-nucleotidase, $\mathrm{Na}^{+} / \mathrm{K}^{+}$- 
ATPase and acetylcholinesterase activities by subchronic treatment with Casearia sylvestris. Phytomedicine 13, 509-514.

Silva, M.I.G., Neto, M.R.A., Neto, P.F.T., Moura, B.A., Amaral, J.F., Sousa, D.P.,

Vasconcelos, S.M.M., Sousa, F.C.F., 2007. Central nervous system activity of acute administration of isopulegol in mice. Pharmacol. Biochem. Behav. 88, 141-147.

Silva, F.O., Silva, M.G.V., Feng, D., Freitas, R.M., 2011. Evaluation of central nervous system effects of iso-6-cassine isolated from Senna spectabilis var. excelsa (Schrad) in mice. Fitoterapia 82, 255-259.

Souto-Maior, F.N., Carvalho, F.L., Morais, L.C.S.L., Netto, S.M., Sousa, D.P., Almeida, R.N., 2011. Anxiolytic-like effects of inhaled linalool oxide in experimental mouse anxiety models. Pharmacol. Biochem. Behav. 100, 259-263.

Steinberg, M., 1987. The use of traditional toxicologic data in assessing neurobehavioral dysfunction. Neurotoxicol. Teratol. 9, 403-409.

Tyrer, P., Owen, R., Dawling, S., 1983. Gradual withdrawal of diazepam after chronic therapy. Lancet, 1402-1406.

Viaud-Delmon, I., Venault, P., Chapouthier, G., 2011. Behavioral models for anxiety and multisensory integration in animals and humans. Prog. Neuropsychopharmacol. Biol. Psychiatry 35, 1391-1399.

Walf, A.A., Frye, C.A., 2007. The use of the elevated plus maze as an assay of anxietyrelated behavior in rodents. Nature Protoc. 2, 322-328.

Wang, W., Zhao, J., Wang, Y.H., Smillie, T.A., Li, X.C., Khan, I.A., 2009. Diterpenoids from Casearia sylvestris. Planta Med. 75, 1436-1441.

Wiggers, H.J., Rocha, J.R., Cheleski, J., Montanari, C.A., 2011. Integration of ligand- and target-based virtual screening for the discovery of cruzain inhibitors. Mol. Inform. $30,565-578$.

Zhang, Z.J., 2004. Therapeutic effects of herbal extracts and constituents in animal models of psychiatric disorders. Life Sci. 75, 1659-1699. 